\title{
Lawsuit puts flu-vaccine contract in doubt
}

A US office tasked with readying the country for influenza pandemics received an unpleasant surprise last week, when creditors filed a lawsuit intended to force one of its new grantees into bankruptcy.

The lawsuit was filed the day before the Biomedical Advanced Research and Development Authority (BARDA) in Washington DC announced it had awarded a US\$35-million contract to Protein Sciences, a biotechnology company in Meriden, Connecticut. The contract is to support the development of vaccines against pandemic flu viruses, such as the H1N1 strain circling the globe. The award could be extended to $\$ 147$ million over five years, and require 50 million doses of vaccine to be produced.

But the company's success or failure may depend on the outcome of a lawsuit filed on 22 June by vaccine maker Emergent BioSolutions of Rockville, Maryland, and two other creditors that say Protein Sciences has failed to pay back more than $\$ 11$ million in loans.

Protein Sciences has developed a way to produce flu vaccines in insect cells - a method that some hope will break the industry's reliance on the tried-and- tested but slow process of making them in chicken eggs. Its seasonal-flu vaccine is being considered by the Food and Drug Administration; a decision about its approval could come this year, says chief operating officer Manon Cox.

In March 2008, the company received word that it would probably win a contract from BARDA; but then Emergent offered to buy it,

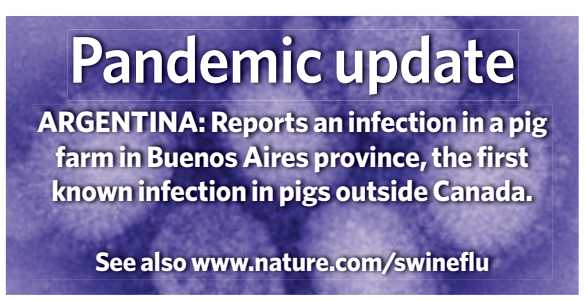

and the two firms entered into negotiations. Concerned that the merger might threaten the company's ability to produce an influenza vaccine, BARDA held back its final decision. "Emergent BioSolutions at that time did not have the necessary know-how, resources and people to use the technology that Protein Sciences had developed," says BARDA director Robin Robinson.

Negotiations between the two companies collapsed when Protein Sciences' shareholders voted against the agreement, but by then the company had already accepted a \$10-million loan from Emergent. BARDA conducted two financial audits of Protein Sciences last year, Robinson says, and assured itself that the company would be able to pay back its creditors. But Cox says that the financial climate, and lawsuits filed by Emergent after negotiations broke down, made it difficult to raise funds.

Although the loan was due to be repaid at the end of May, Robinson says he had not expected a lawsuit, and he declined to speculate about the fate of BARDA's contract until the case is heard in court later this month. "Basically, we just see this as feuding between two companies," he says.

BARDA, meanwhile, will receive an influx of funds from the \$7.7-billion spending on pandemic flu that was signed into law last week. Spending on vaccines is not specified, but the money will be used mainly for the public-health programmes and supplies needed to cope with the H1N1 pandemic, says Robinson, without sacrificing its investments in vaccine technology. Heidi Ledford

\section{UK Met Office hit by cuts to climate project}

The UK government has slashed its financial support for the Met Office's climate programme. The move came in the same week that prime minister Gordon Brown laid out ambitious talk of a US\$100billion fund to help developing countries to cope with climate change (see http://tinyurl.com/ m22pq9).

The Ministry of Defence (MOD) has withdrawn its $\notin 4.3$ million (US\$7 million) in funding for climate research - roughly a quarter of the Met Office's total funding in this area. The change will affect the Hadley Centre for Climate Change in Exeter, the world-class climate-modelling institute whose researchers made key contributions to the most recent assessment report of the Intergovernmental Panel on Climate Change in 2007.
"This news comes as a shock," says climate scientist Martin Parry, formerly of the Met Office and now at the Grantham Institute for Climate Change at Imperial College London. "The UK's core modelling work on climate change has been funded from this source, up to now," he says.

The change does, however, bring the centre more in line with other national climate research centres, very few of which have links to defence funding.

In a statement, an MOD spokesperson said that the cuts, which are effective immediately, were made with a view to "prioritizing success in current operations, such as Afghanistan".

This will be the first time that Met Office climate research has gone without MOD cash.
One-sixth of the agency's total budget of $E 176.5$ million comes from commercial services, but the government, and the MOD in particular, remains its main customer and funder.

In 2007, the MOD signed a three-year deal worth $\notin 12$ million with the Met Office to partfund its Integrated Climate Programme, which makes up the bulk of its climate research. Although the MOD has withdrawn its remaining funding, a Met Office spokesman insisted that the programme is not threatened.

The Department of the Environment, Food and Rural Affairs is committed to providing $£ 4$ million per year until 2011 to the climate programme, and the Department of Energy and Climate Change will provide about $\notin 10$ million in annual funding over the same period.

The Met Office is now in negotiations with these departments, and with the Department for International Development, in an your funding is a of the lost funding. "If they don't recoup it, they are going to be in serious trouble," said Gavin Schmidt, a climate modeller at NASA's Goddard Institute of Space Studies in New York. "Losing 25\% of your funding is a huge deal. Five per cent is generally containable, but $25 \%$ is not an amount you can hope to absorb easily."

Olive Heffernan

For a longer version of this story, see http://tinyurl.com/mlcn7y 